\title{
Participatory Research and Empowerment: A Conceptual Revisit of the Debate on Alternative Social Science Research
}

Youba Raj Luintel

\begin{abstract}
After the 1970s, there has been a growing emphasis on participatory research aimed at capturing people's lived realities of everyday lives. The proponents of participatory research (also called alternative research) build on a critique of what is called "extractive," top-down, and so-called objective empirical research of positivist kind. In contrast, alternative research method embeds research with empowerment and regards survey based conventional research as instrumental. This paper first introduces basic premises of alternative research method together with its philosophical underpinning. Drawing arguments from Robert Chambers the following section compares and contrasts the conventional and alternative research methods. Further, a paradigm shift in social science research in terms of reversals of frame, reversals of modes, reversal of relation and reversal of power is dealt. The final section draws a conclusion that compared to
\end{abstract}




\section{6| Youba Raj Luitel}

survey based, "objective," conventional research method, participatory researches are superior in facilitating knowledge generation process, eventually empowering the people.

Keywords: Conventional research method, participatory research method, empowerment, Robert Chambers

\section{Introduction}

Alternative research method is a body of relatively new and quite different approaches of participatory information gathering and grassroots activism. ${ }^{1}$ It is a process of knowledge-generation which is supposed eventually to empower the people. Alternative research is a semi-structured activity carried out in the field by the people themselves, in collaboration with or often facilitated by a multidisciplinary team, designed to acquire quickly new information about the setting and the livelihoods. According to Robert Chambers, one of the pioneer and populist advocates of alternative research approach, "a family of approaches and methods to enable rural people to share, enhance, and analyse their knowledge of life and conditions, to plan and to act" is what we call alternative research (Chambers 1994a, p. 953).

Participatory research tends to rely primarily on people's knowledge, their praxis and collective mobilisation as viable way of sustainable development. The heightened popularity of the application of ARM, particularly between 1990-2000, sufficiently indicates the paradigm shift from technically sophisticated surveybased research and knowledge-production to a people-centered, informal (or semi-formal), and qualitative approach of knowledge generation. ARM is a group of research approaches including participatory research (Chambers 1983, 1995, 1997), action research (McNiff and Whitehead 2002, Coghlan and Brydon-Miller 2014), subaltern studies (Spivak 1988), and reflective critical social science research (Geuss 1981). Unlike the conventional research method (CRM), the ARM calls for a de-compartmentalisation of (and a closer interaction between) research and development. ARM seeks to challenge the traditional dichotomy of research and action,

1. An earlier version of this paper was published in Sahabhagita, a magazine published by Nepal Participatory Action Network (2002). 
thereby between knowledge and development.

By the term "conventional research" we mean a research approach that tries to "extract" information from the people. The tool employed is predominantly survey questionnaire. In such a research it is the researcher who is supposed to act like an "expert," such that the person uses his/her "expertise" to describe the setting and livelihood conditions, about which rather the local people know better. In such a research, the researcher decides everything - from designing the research protocol, identifying findings, to drawing fantastic recommendations. The local people have little or no say in all these processes (see Cornwall and Jewkes 1995).

Largely critical to positivism, ${ }^{2}$ ARM is implicitly informed by critical theory of Jürgen Habermas. In his Knowledge and Human Interests, Habermas (1972) raised the epistemological discussion of critical theory to a new level by identifying critical knowledge through its orientation to self-reflection and emancipation (also see Outhwaite 1988). The present article seeks to delineate the basic premises of ARM and summarises its main arguments against the CRM. In so doing efforts have been made to depict basic points that are used to juxtapose it with CRM. The pertinent and underlying questions are: Why is CRM "conventional"? Under ARM, how do researchers ensure that people's reality is well captured/addressed? Whose voices are real people's voices? In ARM, how actually is power handed over to the people? How does ARM envisage to "empowering" the people? These are some of the basic questions we will try to address in this article. Drawing on Chambers's famous argument of "reversals," I finally provide justifications for ARM's critique of CRM.

2. Positivism is an epistemological approach in social sciences that assumes that social phenomena can be observed, analyzed and interpreted objectively and without any value-bias. The core assumption of positivism is that social science is identical in its logic to natural science. It believes that social science involves the search for general laws about empirical phenomena and argues that discovery and explanation depend upon a rigorous empirical scrutiny of the phenomena under question (for an introductory text on positivism see Pijl 2009). The sociological tradition of positivism begins right from August Comte and Emile Durkheim. 


\section{Basic Premises and Philosophical Underpinning of Participatory Research}

In the wake of the "success" of the Green Revolution ${ }^{3}$ during the 1970s, many of the shortcomings of the CRM became apparent (McCracken et al. 1988). CRM, at that time, had been directed not to the diverse realities of the people but to "increasing the yield potential of the major cereal staples" (ibid). Then it was felt that research should focus not only on the technical aspect of intervention (such as the cereal), but also on the "problems of the farmers" who survived in more poorer, precarious and heterogeneous environments. Subsequently, a number of research approaches evolved in that direction.

The actual history of ARM begins with the emergence of Rapid Rural Appraisal techniques in the late 1970s and the early 1980s in and around the Institute of Development Studies at the University of Sussex. Initially RRA was a confluence of many similar research initiatives, such as activist participatory research, agro-ecosystem analysis, applied anthropology, and field research on farming systems, popularly known as farming system research (see Chambers 1994a). What they all were common is in their focus on applied aspects. They were not only rapid and participatory but also holistic and flexible. RRA has been refined much more than it had been used initially. Now we have Participatory Rural Appraisal (PRA) and also Participatory Learning and Action (PLA) developed during the late 1990s, both of which substitute or complement RRA, as the latter was considered as quick and dirty.

The ARM has much to do with alternative development

3. By the mid-1960s, hunger and malnutrition were widespread, especially in Asia, which increasingly depended on food aid from rich countries. In response, the Rockefeller and Ford foundations took the lead in establishing an international agricultural research system to help transfer and adapt scientific advances to the conditions in developing countries. The first investments were in research on rice and wheat, two of the most important food crops for developing countries. The breeding of improved varieties, combined with the expanded use of fertilizers, other chemical inputs, and irrigation, led to dramatic yield increases in Asia and Latin America, beginning in the late 1960s. In 1968, U.S. Agency for International Development (USAID) Administrator William S. Gaud coined the term "Green Revolution" to describe this phenomenal growth in agriculture (see Hazell 2003). 
paradigm that calls for "putting people first" (Cernea 1985), "putting the last first (Chambers 1983), or just reversal, "putting the first last" (Chambers 1997). The basic tenet is that "people are - and should be - the starting point, the center, and the end goal of each development intervention" (Cernea ibid, p. 3).

The ARM has two philosophical underpinnings. First, it seeks an "optimal ignorance" on the part of the researcher. It means, it suggests to seeking only very necessary information, rather than becoming unnecessarily comprehensive. It is not necessary to collect data on everything; hence, it is important to know "what facts are not worth knowing" (Chambers 1985, p. 403). McCracken et al. have a similar opinion (McCracken et al. 1988, p. 12). Secondly, ARM believes in "appropriate imprecision" (Chambers 1985). It believes that knowledge, facts and information that show the magnitude and direction of change to be ideally enough (Chambers ibid). In other words, painstaking precision and minute accuracy are not always needed. Instead, it is argued, the degree of accuracy and completeness of a research can be maximised through the process of triangulation (McCracken et al. 1988).

\section{Conventional and Alternative Research Methods Compared}

ARM is based on the belief that research is never a value free enterprise. No research is politically neutral. ARM asserts that every research stands in the backdrop of certain degree of political justification and entails certain social consequences. Judgments and claim makings - both of which are an integral part of any research - are largely political activities that seek to posit one's own research in certain "correct" position. In this sense, every research has certain power element - from its very conceptualisation to the decisions related to institutional affiliations and funding. In every research power relations are mediated through knowledge and knowledge is constructed and reconstructed through discourse and narratives. If every research has to do - to a varying degree - with construction, production and circulation of knowledge and claim-making, how can research be value-free and apolitical?

If a process of knowledge production does not include people it is concerned with, for example, this would have a clear political 


\section{0| Youba Raj Luitel}

implication on their exclusion and marginalisation from knowledge discourse. It is in this context that every research project considered as a tool of empowering ${ }^{4}$ or disempowering people (Singh and Titi 1995).

Unlike this, CRM is formal and too much inclined to data and statistical inferences by way of questionnaire-based survey. The direction of such a research is often top down (McCracken et al. 1998). The nature of such research is mostly extractive (extracting the information from people, recycling their knowledge in to claim making as one's own findings, and never turning back to the people). There is no space for people's contribution, during and after the research, on to whom the research was intended to benefit. People are considered as the mere "respondents" and not the stakeholders, as if they are waiting there for someone to come and respond to what has been asked for.

Firstly, CRM contains a set of questions designed previously and outside the setting of the research. Secondly, it ignores the fact that people might have their own observation, categorisation, and way of comprehension and interpretation, which may not always fit into the pre-coded format of the questionnaire. Finally, the "respondents" are selected not on the basis of the needs and the dynamics of the research but on "random" basis, which may be artificially representative of the whole universe, but runs the risk of distortion by default. Beside, the duration of the entire research process of any conventional research is relatively long; sometimes it may take couple of years by the time research findings are published. (Census reports, for example.) By this time the dynamics of research setting might get changed, thus posing a challenge about the policy and academic implications of such research. Chambers tacitly depicts the proven inefficiency of CRM:

[...] the survey questionnaire ... if asked are never coded, or if coded never punched, or if punched never processed, or if processed and printed out never examined, or if examined never analysed or written up, or if analysed and written up never read, or if read never understood or remembered, or if understood and remembered never actually used to change action. (Chambers 1985, p. 402)

4. The term "empower" is used here to refer to investing on to transfer power, to authorize and to enable the local people. 
Dhaulagiri Journal of Sociology and Anthropology Vol.11, 2017|121

Table 1 summarises the basic differences between conventional and alternative research approaches. It shows that conventional research is top-down, imposed, and based on outsiders' decision that treats people as objects.

Table 1: Shifting paradigm of research from conventional to alternative

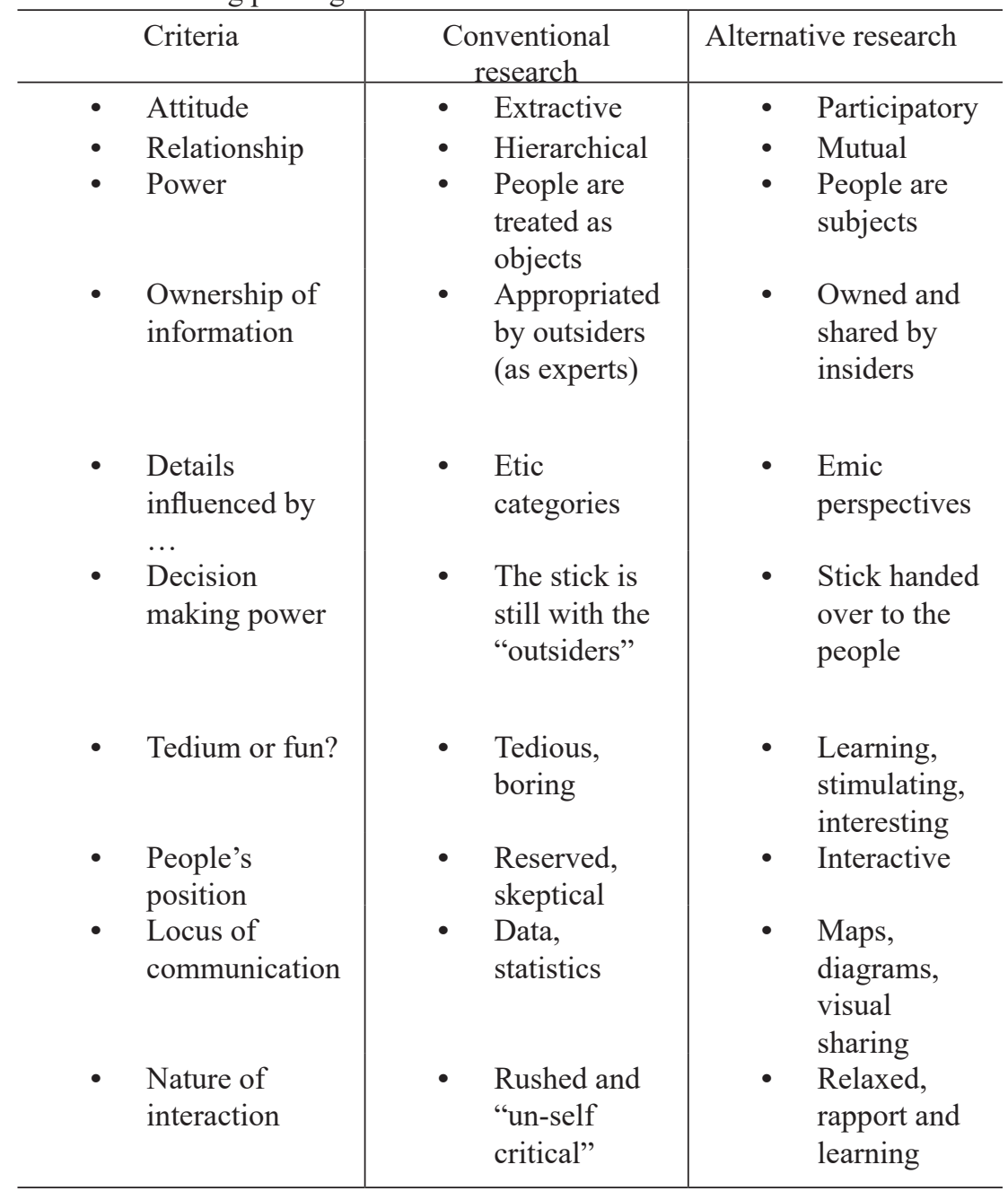

Source: Adapted from Chambers (1992, pp. 39-46).

Whose reality counts? This is one of the problematic Chambers put forward as one important development agenda which he also 


\section{2| Youba Raj Luitel}

repeatedly asserted at the Social Development Summit, Stockholm in 1994. Since then, this has become a robust question that appeals for a self-critical assessment on the part of development practioners. Fourteen years later, Chambers (1997) came up with a bolder and radical proposition of "putting the first last" suggesting that those who are at the upper echelons of society (elites, aristocrats, rich, powerful, the ruling class, etc.) need to step down to pave the way for empowering the commoners. How pragmatic this proposition is? Whether the stepping down of the powerful group automatically paves the way for a process of common people's empowerment? These are some of the few intriguing puzzles one can be skeptical about, however. Chambers' assertion comes from a good faith, however, that if uppers give up something, social sacrifice would be for the benefit of all - sort of eventual win-win game - in order to empower the poor and the excluded.

Although rural people are often poor, vulnerable, live in isolation and suffer from what Chambers (1995) calls seasonality, powerlessness and humiliation; yet they are the ones who know best how to maintain sustainable livelihoods. "On livelihoods, the strategies of the poor are usually diverse and often complex" says Chambers (1985). But both "rural development tourism" (a phrase Chambers uses to refer to PRA) and traditional anthropological fieldwork (that seeks to explore the exotic, the native) tend to bypass local people's knowledge. It is in this pursuit that Chambers $(1985,1997)$, Cernea (1985), Uphoff (1982) and Korten and Clauss (1984) contributed for a paradigm of reversals that would place people at the centre.

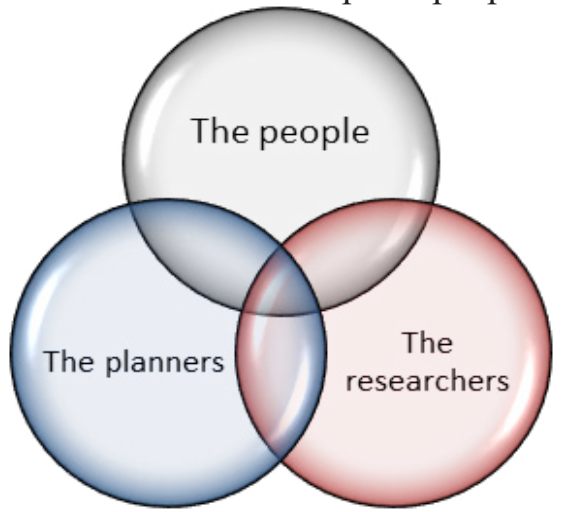

Figure 1: Key actors and stakeholders of the grassroots-based progressive learning proce 
The powerful underlying assertion has been that there should be development around people and not the people around development. Although, this may sound little populist argument for some, I assert that, one can smell the persuasive power it carries in subsequent paradigm shift in the whole lot of development discourse. This paradigm shift is reflected, for example, in the notion of human development that (lately though) admits the value of keeping people at the centre of development, and pleads for human flourishing and/or enlarging people's choices (UNDP 1990 and Haq 1995), that recognises the value of freedom (Sen 1999), and capability enhancement (Nussbaum 2000).

Handing over the stick: The proponents of ARM have advanced methods of appraisal and research, planning and implementation, and evaluation in such a way that research and development can no longer be separated. Both go hand-in-hand, or sometimes in a back-and-forth motion, demanding that the researchers and planners work in a very close consultation and interaction with the people, such that it allows optimal mutual learning (see Figure 1). This relationship is characterised with cooperation, complementarity, conflict, resistance, negotiation and compliance.

Both the conventional (survey-based) and anthropological (field-based) $^{5}$ research are extractive. Extraction does not help people to enhance their praxis. In either case, it is the researcher who predominates the interaction. In ARM, unlike the above, people are an integral and active part of the process. People are also the decision-makers and whose hands the authority of what to do and how to do rest. More importantly, people are encouraged to exercise their own praxis and assertion. This is what we call "handing over the stick" to the people.

Research for empowerment: ARM has clear potential of empowering the masses, which the CRM definitely and inherently cannot. First, ARM is rapid, cost effective and actors-friendly approach of information-gathering. The accuracy, relevance, and timeliness of information gathering mean that it can be applied immediately into practice. Through transect walk, social mapping

5. See, for example, Shah's (2018) A Project of Memoreality, and Maskarinec's (1995) The Rulings of the Night. 


\section{4| Youba Raj Luitel}

and wellbeing mapping, for instance, the villagers can arrive at certain strategy of their collective interests. The success of ARM to empowering people through "problem-posing and problem-solving" techniques and mobilisation of community has been well practiced in rural Bangladesh by the Bangladesh Rural Advancement Committee (see Singh and Titi 1995).

Secondly, ARM is informed of liberation philosophy (Kruijer 1987). ARM, therefore, seeks dual transformation in society at once: while the masses are released from the elite control over material production, on the one hand, they are also liberated from the experts' monopoly over knowledge production, on the other (Rahman 1993). Thirdly, the Freirian approach (Freire 2000, 2013) of emancipating the oppressed has been one of the most effective ways of "conscientization" of the masses and developing genuine people's praxis. Mobilisation of people's own assertion of their knowledge, skills and resources is one of the important outcomes of ARM. How does ARM actually empower the people? Giving an example of participatory research, Chambers argues:

Good PRA empowers. Those who, through PRA, express and share what they already know, learn through that expression and sharing. Those who investigate and observe add to their knowledge. Those who analyse become yet more aware and reach new understanding. Those who plan and then implement what they have planned take command, and further learn through the experience of action. (Chambers 1992, p. 56)

\section{A Paradigm Shift to Alternative Research Method}

ARM is inherently critical to CRM. This is primarily due to the paradigm shift in research and development, a shift from "topdown" to "bottom-up," from development intervention to enhancing people's praxis, from domination to reciprocity and mutuality. Chambers calls it "reversals." The term "reversals" refers here to directions, away from normal professional practices and towards their opposite (see Chambers 1983, 1994b). In this section we will try to elaborate some of them very briefly. To Chambers the reversals are of four kinds, as follows.

Reversals of frame means reversal "from etic to emic," from the knowledge, categories and values of outsider professionals to those of insider local people (Chambers 1994b, p. 1262). Survey 
research have closed-ended pre-set and pre-coded questionnaire. So it ignores the indigenous knowledge and implies that people's knowledge is not valid vis-à-vis the knowledge of the experts. On the contrary, semi-structured interviews of PRA, for instance, are open and flexible. They apply people's frame of reference for enquiry. For example, in PRA the local people themselves identify and categorise who are poorer in their locality and who are not. They often use their own criteria for such a distinction.

Reversals of modes refer to the ways information is collected. In survey questionnaire the respondents are approached on individual basis. Participatory research, however, is group-based and dwells on collectivity. "Groups can have an overlapping spread of knowledge which covers a wider field and cross-checks" (Chambers 1992, p. 41). Group interactions also allow to discussing some of the critical issues - issues in which an individual may feel unsure about. In several ways the researcher predominates the respondent in CRM, such as s/he determines the agenda, keeps eye contact, and asks series of closed-ended questions one-to-one - which is often embarrassing and humiliating to the former. In contrast, participatory methods are visual and open to all. In diagramming, for example, even an illiterate person can make sense and share his/her ideas and observation.

Reversal of relation is a result of the reversals of frame and mode. It negates and reinforces reversal of relations between outsiders (read "researchers") and the insiders (read "the common people") from suspicion and reserve to confidence and rapport (see Table 1). Reversal of power refers to ARM's focus on abdication of power and passing much of the initiative and control to local people. Unlike this, conventional research tends to empower the researchers themselves (either by expanding and ensuring consultancy or career promotion, for example).

\section{Conclusion}

This brief discussion shows that CRM and ARM have contrasting premises, arguments and ways of approaching the people. They are different not only in their assumption (see Table 2), but also on the level of efficiency. CRM has the legacy of modernisation 


\section{6| Youba Raj Luitel}

(and later, neoliberal) arguments, where as the ARM is inspired by critical theory. The emergence of ARM is partly a reflection of the popularity of new paradigm research, whose focus is not on facts and information but on "getting the process started." A short history of ARM itself unpacks that it did emerge in the context of many shortcomings of CRM. Although anthropologists often insist that it needs much time and immersion to create rapport with the people (which they claim rapid appraisal tools cannot accomplish), experience shows that if our behavior and attitude are proper, adaptive as well as participatory, good rapport usually comes quickly (Chambers 1992).

Table 2: Contrasting assumptions of CRM and ARM

\begin{tabular}{|c|c|c|}
\hline Criteria & Conventional research & Alternative research \\
\hline $\begin{array}{l}\text { Ontology of } \\
\text { research }\end{array}$ & $\begin{array}{l}\text { The researcher is } \\
\text { knowledgeful }\end{array}$ & $\begin{array}{l}\text { The research } \\
\text { "facilitates" } \\
\text { knowledge generation } \\
\text { process }\end{array}$ \\
\hline $\begin{array}{l}\text { Cosmology of } \\
\text { research }\end{array}$ & $\begin{array}{l}\text { Instrumentalism (research } \\
\text { as an instrument to extract } \\
\text { data from the field) } \\
\text { Focus on deductive } \\
\text { research }\end{array}$ & \begin{tabular}{|l} 
Relationalism \\
(research as a means \\
of sharing knowledge \\
on local livelihoods) \\
Focus on inductive \\
research
\end{tabular} \\
\hline $\begin{array}{l}\text { Epistemology } \\
\text { of research }\end{array}$ & $\begin{array}{l}\text { Positivism (research is and } \\
\text { can be neutral and value- } \\
\text { free enterprise) } \\
\text { Subject-object division }\end{array}$ & \begin{tabular}{|l} 
- \\
reflectivism (no \\
and neutral) \\
Subject-subject \\
relation
\end{tabular} \\
\hline
\end{tabular}

Source: Adapted from Chambers (1994a) and Escobar (1992).

Finally, the development of ARM also implies that there are reversals of dominance: from "ours" to "theirs," and from extraction to empowerment. Chambers argues that a good participatory research identifies the weaker and marginalised ones, empowers them and attempts to attain equity. It is in this conceptual backdrop that we argue that ARM is more participatory, people-centered and flexible for the process of empowering the people. The process of ARM, 
Dhaulagiri Journal of Sociology and Anthropology Vol.11, 2017|127 unlike CRM, breaks the ice of empowerment everlastingly.

\section{References}

Cernea, Michael M. (1985). Putting People First: Sociological Variables in Rural Development, New York: Oxford University Press.

Chambers, Robert. (1983). Rural Development: Putting the Last First, London: Longman.

Chambers, Robert. (1985). "Shortcut methods of gathering information for rural development projects," in Michael M. Cernea (ed.) Putting People First: Sociological Variables in Rural Development, New York: Oxford University Press, pp. 399-415.

Chambers, Robert. (1992). Rural Appraisal: Rapid, Relax and Participatory, IDS Discussion Paper 311, Institute of Development Studies, The University of Sussex.

Chambers, Robert. (1994a). "The origin and practice of participatory rural appraisal," World Development, vol. 22, No. 7, pp. 953-969.

Chambers, Robert. (1994b). "Participatory Rural Appraisal (PRA): analysis of experience," World Development, vol. 22, No. 9, pp. 1253-1268.

Chambers, Robert. (1995). Poverty and Livelihood: Whose Reality Counts? IDS Discussion Paper 347, Institute of Development Studies at the University of Sussex.

Chambers, Robert. (1997). Whose Reality Counts? Putting the First Last, London: Intermediate Technology Publications.

Coghlan, D. and M. Brydon-Miller. (2014). The SAGE Encyclopedia of Action Research (vols. 1-2), London : SAGE Publications Ltd.

Conway, G. (1986). Agro-ecosystem Analysis for Research and Development, Bangkok: Winrock International.

Cornwall, Andrea and Rachel Jewkes. (1995). "What is participatory research?," Social Science Methodology, vol. 41(12), pp. 1667-1676.

Escobar, Arturo. (1992). "Reflection on 'development': Grassroots approaches and alternative politics in the Third World," Futures, vol. 24, Issue 5. pp. 411-436. 


\section{8| Youba Raj Luitel}

Freire, Paulo. (2000). Pedagogy of the Oppressed (with an introduction by Donaldo Macedo), New York: Bloomsbury Academic (originally published in 1968).

Freire, Paulo. (2013). Education for Critical Consciousness, New York: Bloomsbury Academic (reprint edition).

Geuss, Raymond. (1981). The Idea of a Critical Theory: Habermas and The Frankfurt School, New York: Cambridge University Press.

Gypmantasiri, Phrek. (1980). An Interdisciplinary Perspective of Cropping System in the Chaing Mai Valley: Key Questions of Research, Chaing Mai: Multiple Cropping Project, University of Chaing Mai.

Habermas, Jürgen. (1971). Knowledge and Human Interests, Boston: Bacon Press.

Haq, Mahbub. (1995). Reflections on Human Development, New York: Oxford University Press.

Hazell, Peter B. R. (2003). "Green revolution," in J. Mokyr (ed.), The Oxford Encyclopedia of Economic History, Oxford: Oxford University Press, pp. 478-480.

Korten, David and Rudi Clauss (eds.). (1984). People-Centered Development: Contributions toward Theory and Planning Framework, Connecticut: Kumarian Press.

Kruijer, G. J. (1986). Development through Liberation: Third World Problems and Solutions, Basingstoke: MacMillan Education.

Maskarinec, Gregory G. (1995). The Rulings of the Night: An Ethnography of Nepalese Shaman Oral Texts, Wisconsin: University of Wisconsin Press. McCracken, J. A., J.N. Pretty and G.R. Conway. (1988). An Introduction to Rapid Rural Appraisal for Agriculture Development, London: International Institute for Environment and Development (IIED).

McNiff, Jean and Jack Whitehead. (2002). Action Research: Principles and Practice, second ed., London and New York: RoutledgeFalmer.

Nussabaum, Martha. (2000). Women and Human Development: The Capabilities Approach, Cambridge, UK: Cambridge University Press. 
Outhwaite, William. (1988). Habermas: Key Contemporary Thinkers, Cambridge: Polity Press.

Pijl, Kees Van Der. (2009). "Positivism and Sociology," in A Survey of Global Political Economy, Sussex: Centre for Global Political Economy, University of Sussex, pp. 59-87.

Rahman, M. D. Anisur. (1993). People's Self Development: Journey through Experience, London: Zed Books.

Rhodes, Robert. (1982). The Art of Informal Agricultural Survey, Lima: International Potato Center.

Sen, Amartya. (1999). Development as Freedom, Oxford: Oxford University Press.

Shah, Saubhagya. (2018). A Project of Memoreality: Transnational Development and Local Activism among Rural Women in Nepal, Lalitpur: Social Science Baha and Himal Books.

Singh, Naresh and Vangile Titi. (1995). Empowerment towards Sustainable Development, London: Zed Books.

Spivak, Gayatri Chakravorty. (1988). "Can the Subaltern speak?" in Cary Nelson and Lawrence Grossberg. (eds.). Marxism and the Interpretation of Culture, Chicago: University of Illinois Press, pp. 271-316.

UNDP. (1990). Human Development Report 1990, New York: Oxford University Press.

Uphoff, Norman. (1992). Learning from Gal Oya: Possibilities for Participatory Development and Post-Newtonian Social Science, New York: Cornell University Press.

Luintel, Youba Raj (ORCID: 0000-0003-4199-0293) earned his $\mathrm{PhD}$ in Sociology from Newcastle University, United Kingdom in 2010, and Master of Arts degree in Development Studies from the Institute of Social Studies, The Hague, The Netherlands in 2000. $\mathrm{He}$ is Associate Professor at Tribhuvan University and teaches at the Central Department of Sociology. He has published two books and several journal articles. His areas of research interest fall in livelihoods, poverty and social inequality, market and social change, disaster, vulnerability and resilience, and gender and social change. Email: y.luintel@gmail.com] 